\title{
POR UN ESPACIO LITERARIO CONTINUO
}

POR

\author{
ERNEST PÉPIN
}

Somos fragmentaciones dispersas en el mar Caribe. Qué más decir que nuestros sobresaltos de islas fueron el teatro de rivalidades coloniales seguidas de emergencias nacionales que, a lo largo de la historia, han amarrado nuestras memorias a problemáticas recurrentes, a infranqueables pantanos, a polaridades fijas que nos obligan a identificarlos y cuestionarlos.

Así, hablar de espacio literario continuo es postular un deseo que denota en profundidad lo discontinuo, la diseminación, la segmentación, como falta e imperfección de una totalidad soñada o al menos reivindicada.

Entonces, evidentemente, nos aferramos a insularidades confinadas, prisioneras y sordas que se oponen, de hecho, a la construcción de un lenguaje común, de un lugar común. Nos arriesgamos a pensar que ese lenguaje común es un condensado de lenguas diversas que levantan muros y fabrican torres.

Enumeramos estatus políticos diferentes: (Estados-naciones/Departamentos franceses/ Estados asociados), a través de los cuales se miden los grados de soberanía y los campos a veces inciertos de la emancipación.

Se puede llegar hasta invocar la irreductible especificidad de las culturas, sus opacas trascendencias y el trazado singular de sus recorridos respectivos.

Allí hay una evidencia tan legible que nos lleva a dudar de la evidencia y a buscar, más allá de las máscaras del desmembramiento (construido y sufrido), la cara desnuda de una continuidad, de una semejanza, en el seno de la cual se aglutinan palabras perdidas, palabras reformuladas, palabras solidarias, palabras en eco. Todas ellas no traman la unidad sino el entrelazado (hecho de tangentes, de distorsiones y hasta de oposiciones), de nuestros complementarios, el redoblamiento de nuestras formulaciones. En un palabra, ellas siguen la pista de la continuidad de un espacio literario adosado al murmullo de las olas, a las variaciones de nuestras geografías, a las turbulencias de nuestras tierras, a esta necesidad de recoser lo heterogéneo para expresar lo humano, de sondear nuestras sociedades para revelar las líneas de fracturas pero también el tropismo de las convergencias y la incandescente lava de nuestros imaginarios. 
Allí se encuentran campos de emergencia que, fuera de todo compartimento, estructuran un discurso que se va convirtiendo en protesta, denuncia, afirmación, legitimación, refundación, antes de devenir en inéditas complejidades engendradas por las migraciones, la errancia y la mundialización creolizada de nuestras existencias.

Entre el Cuaderno de un retorno al país natal y Soy un escritor japonés de Dany Laferrière ¡Cuántos caminos recorridos!

Somos en gran medida exiliados vueltos a enraizar.

Recomposiciones fermentadas, recreaciones trágicas, líricas, épicas y, a menudo, problemáticas.

Nuestra palabra literaria lleva las huellas de los abismos del mar, de la memoria perturbada de la partida y la llegada, del impulso vital de una reconquista de sí mismo. Los traumas de las relaciones raciales, las fragmentaciones de nuestras culturas populares, las fricciones rugosas de los torbellinos de nuestras historias no faltan para modelar nuestras literaturas.

Nos hemos defendido contra las jerarquizaciones mutiladoras, los fetichismos de los centros arrogantes, las imposiciones de las lenguas dominantes. Hemos exigido nuestros derechos a la palabra - a nuestras formas de palabra- al reconocimiento de nuestras identidades, a nuestro deber de compartir el mundo con el mundo. Hemos reivindicado la inscripción de nuestras heterogeneidades en el muro de un Occidente demasiado ciego, demasiado rígido, imperial.

¡Sólo nos hemos defendido! Hemos derrocado perspectivas, cimarroneado certezas o herencias, degradado las fijaciones atávicas, moldeado formas nuevas, hecho de Babel no una torre, sino un horizonte.

¡De ahí nuestra creatividad!

¡De ahí nuestra vitalidad!

¡De ahí nuestra insolencia!

¡De ahí nuestra literatura!

Una literatura que se construyó a pesar de todo con constantes entre las cuales podemos citar:

"El escape a los encierros" para deshacerse de las trabas existenciales, sociológicas o históricas.

Cito como ejemplos: La Rue Cases-Nègres de Joseph Zobel, In the castle of my skin de Georges Lamming, Une enfance créole de Patrick Chamoiseau...

"La afirmación de la négritud" con Aimé Césaire, Léon-Gontran Damas, Claude Mac Kay, Luis Pales Matos, Nicolás Guillen, Edward Kamau Brathwaite, René Depestre... "La antillanidad" con Édouard Glissant, Earl Lovelace, Derek Walcott...

"Los modos de creolización” con Édouard Glissant, Earl Lovelace, Alejo Carpentier, Marcio Veloz Maggiolo, Gabriel García Márquez, Gisèle Pineau, Simone SchwarzBart...

"Los desafíos cimarrones” con Aimé Césaire, Roberto Fernández Retamar, Édouard Glissant... 
"El exilio y las migraciones" con Maryse Condé, Naipaul, Edwidge Danticat, Dany Laferrière...

"Las rupturas engendradas por la modernidad y la problemática de lo urbano": Leonardo Padura, Alfred Alexandre, Earl Lovelace, Juan Gutiérrez...

No estoy seguro que mi nomenclatura, seguramente incompleta, sea tan rígida como mi presentación porque tanto unos como otros pueden mezclar las temáticas en una espiral aún inconclusa.

Quisiera simplemente expresar aquí que nuestras literaturas caribeñas tienen una relación a pesar de las supuestas divisiones.

Vamos todos en resistencia, en disidencia estética, en aclamaciones barrocas, en pólenes dispersos, en cartografías insatisfechas, en hombres-esquejes, en travesías imprevisibles de la escritura.

Evidentemente, las historias nacionales llevan todo el peso, pero ¿no tienen ellas la voluntad persistente de concluir las descolonizaciones? ¿No son ellas un ascenso, a veces, caótico (o confuso) hacia la luz del puente de las conciencias?

Por supuesto, hay mucho que decir sobre el lugar de las mujeres, sus combates, sus lecturas emancipadoras, sus escrituras descentradas. Ellas me parecen unas sondas de fallos, reveladoras de lo disimulado, quebradoras de fronteras, arquitectas de una nueva relación de la dominación y el dominado.

Habría mucho por decir sobre la efervescencia de la oralidad, las transgresiones verbales o de escritura que, aquí y allí, transforman las lenguas del Caribe.

Lo que importa es que todos seamos ecos trabados, espejos inquietos de un lenguaje sub-marino que tal vez sea nuestra más bella fundación. Nuestras islas bailan, se acercan, se alejan, se arremolinan, están en trance, en corro, se abrazan. Pero ¿quién expresará el espacio solidario de sus cantos?

Entre Anthony Phelps (Mon pays que voici), Hector Poullet (Mi péyi la), Pedro Mir (Hay un país en el mundo) ¡cuántos reencuentros! Literaturas inquietas, somos esas literaturas que, a contracorriente de los mitos fundadores, tienden la mano al continuo de un país siempre por reinventar: ¡El Caribe de los imaginarios!

Nos corresponde comprender que el imaginario, lejos de ser un capricho de los pueblos, es por el contrario la herramienta primera para desarticular las trampas tendidas por los conformismos, los atavismos, los racismos y todo lo que procede de la exclusión del hombre por el hombre.

Y es ahí donde el Caribe tiene algo que decir porque siempre ha titubeado en los márgenes, armado sincretismos, dudado de la legitimidad de los administradores del mundo, cosechado imprevistos, experimentado adaptaciones innovadoras porque siempre su objetivo fue construir un mundo que contara en su diversidad matricial.

En nuestros lugares, el mundo se hace carne con la carne de los otros y se rebela contra toda monocromía, contra toda uniformización. Tantas ciudades chisporrotean

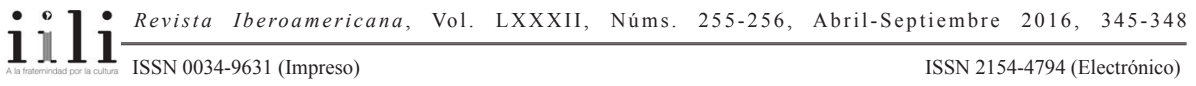


de luces desconocidas levantando a las farolas el corazón sangriento de las memorias desconsoladas. Tantos pasos vuelven de la taberna húmida de los infortunios y bajo los puentes de la soledad atraviesan el agua salada de nuestras historias y a veces se entierran bajo nuestros sueños.

Nuestras lenguas han adherido a países nuevos y han cavado las galerías donde nos metamorfoseamos en un más allá de las lenguas.

Sólo la lengua de nuestros libros podrá hablar por nosotros del esplendor trágico de los viajes sin retorno, de la fisura de lo discontinuo pero también del embrollo de nuestras postulaciones. Ella lleva el testimonio sincero de nuestro andar, de nuestro impulso y de nuestra incertidumbre.

Entonces ¿qué hacer?

Si queremos volver a coser el tejido, trenzar el continuo de nuestras literaturas, debemos cultivar nuestro multilingüismo de manera abierta, vivir de lleno nuestras culturas plurales en una poética verdadera de la relación. Pero para eso debemos descolonizar las herramientas, los medios, las políticas que tienden a encerrarnos. Esto significa comprender que el espacio no es un país, que la lengua no es una prisión. Los invito entonces a convertirse no en los aduaneros de la literatura sino en fronterizos, pasadores que transmiten de mano en mano otro sol. Esta es la obra que ha comenzado nuestro Congreso de Escritores del Caribe. ¡Así valen nuestros encuentros!

¡Gracias por haberme escuchado!

Gosier, 06 de abril de 2011

Traducido por Mariella Aita, Universidad Simón Bolívar, Caracas 